\title{
Primary Pulmonary Diffuse Large B-Cell Lymphoma
}

National Cancer Institute

\section{Source}

National Cancer Institute. Primary Pulmonary Diffuse Large B-Cell Lymphoma. NCI

Thesaurus. Code C45605.

A diffuse large B-cell lymphoma that is localized to the lungs at the time of presentation. Signs and symptoms include cough, dyspnea, and hemoptysis. 